\title{
Hippuric acid, phenol, and trichloroacetic acid levels in the urine of Japanese subjects with no known exposure to organic solvents
}

\author{
MASAYUKI IKEDA AND HATSUE OHTSUJI \\ Department of Public Health, Kyoto University Faculty of Medicine, Kyoto, Japan
}

\begin{abstract}
Ikeda, M., and Ohtsuji, H. (1969). Brit. J. industr. Med., 26, 162-164. Hippuric acid, phenol, and trichloroacetic acid levels in the urine of Japanese subjects with no known exposure to organic solvents. Urine samples from 36 male and 30 female university students and 31 male factory workers with no known exposure to industrial organic solvents were analysed for hippuric acid, phenol, and trichloroacetic acid, which are the major metabolites of toluene, benzene, and trichloroethylene respectively. The normal levels were less than $1.4 \mathrm{~g} . / 1$. for hippuric acid, less than $80 \mathrm{mg}$./1. for phenol, and less than $1 \mathrm{mg}$. $/ 1$. for trichloroacetic acid. No evidence was obtained to suggest that correction for urine concentration with either specific gravity or creatinine concentration minimizes individual variation of metabolite levels.
\end{abstract}

Recently a number of papers have been reporting the increased levels of metabolites in the urine from workers exposed to various organic solvents (Soucěk and Vlachová, 1960; Walkley, Pagnotto, and Elkins, 1961; Pagnotto, Elkins, Brugsch, and Walkley, 1961; Ogata, Sugiyama and Moriyasu, 1962; Elkins, Comproni, and Pagnotto, 1963; Salmowa, Piotrowski, and Neuhorn, 1963; Ikeda and Kita, 1964; Van Haaften and Sie, 1965; Rainsford and Lloyd Davies, 1965; Docter and Zielhuis, 1967; Pagnotto and Lieberman, 1967; Ogata and Nagao, 1968; Ogata, Nagao, and Tomokuni, 1968; Tanaka and Ikeda, 1968). Because some of these metabolites can originate non-industrially, for example from food (Quick, 1931), it was important to determine the levels of metabolites in the urine of non-exposed Japanese subjects. Hippuric acid, phenol, and trichloroacetic acid were chosen because their parent substances (toluene, benzene, and trichloroethylene) are among the most important organic solvents.

\section{Materials and methods}

Urine samples

Sampling was conducted in April. Second morning urines were sampled from university students around 10 a.m. Workers in three factories were asked to urinate at 1 p.m. and the urines voided later, around 3 p.m., were sampled. Unless otherwise specified, the subjects had had no known exposure to industrial organic solvents for at least one week prior to the sampling.

\section{Chemical and statistical analyses}

Hippuric acid Hippuric acid was determined essentially by Ogata et al.'s modification (1962) of the method of Gaffney, Schreier, DiFerrante, and Altman (1954). Fresh urine, 0.01 to $0.05 \mathrm{ml}$., was spotted on Toyo No. 525 paper (roughly equivalent to Whatman No. $3 \mathrm{~mm}$. paper) along a $2.5 \mathrm{~cm}$. line and air-dried. The paper was subjected to ascending chromatography with $n$-butanol: acetic acid: water $(4: 1: 1$, by vol.). When the solvent had risen $20 \mathrm{~cm}$., the paper was air-dried, sprayed with $4 \%$ dimethylaminobenzaldehyde in acetic anhydride (saturated with sodium acetate), and heated in an oven at $130^{\circ} \mathrm{C}$. for 3 minutes. An area of $6 \times 6 \mathrm{~cm}$., which included the orange spot, was taken, and the dye was extracted into $6 \mathrm{ml}$. of methanol. Extinction was measured at $460 \mathrm{~m} \mu$.

Phenol Determination of phenol was as described elsewhere (Ikeda, 1964). Phenol in the acid-hydrolysed 
urine was extracted into ether and was determined colorimetrically after the indophenol reaction with Gibb's reagent at $p \mathrm{H} \mathbf{1 0} 0$.

Trichloroacetic acid and total trichloro-compounds Colorimeteric determination of both trichloroacetic acid and total trichloro-compounds with Fujiwara reaction was as previously described (Tanaka and Ikeda, 1968).

Creatinine Creatinine levels were measured by a micromodification of Folin's method (1914). To $0.2 \mathrm{ml}$. of saturated picric acid solution was added 0.01 to $00.030 \mathrm{ml}$. of the urine, followed by $0.1 \mathrm{ml}$. of $10 \% \mathrm{NaOH}$, and they were mixed well. After standing at room temperature for 10 minutes, the mixture was diluted with $3.0 \mathrm{ml}$. of water and the extinction at $490 \mathrm{~m} \mu$ was measured.

Urine density Results were adjusted in some instances to a specific gravity of urine of $1 \cdot 016$, as described by Elkins and Pagnotto (1965).

Statistical analysis As the standard deviations of the observed values were often as high as $70 \%$ of the means, and a normal distribution appeared not to hold in these circumstances, fiducial limit ranges were calculated on the assumption that a log-normal distribution would be applicable (Heath, 1967).

\section{Results and discussion}

The results are summarized in the Table. The mean specific gravity of the urine samples was closer to the values reported by Rainsford and Lloyd Davies (1965) and Van Haaften and Sie (1965) than to that reported by Elkins and Pagnotto (1965).

Practically no Fujiwara-reaction-positive substances were observed in the normal urine samples. Oxidation of the urine to convert trichloroethanol to trichloroacetic acid (Tanaka and Ikeda, 1968) did not give significant increases in Fujiwara-reactionpositive substances. Thus, the concentrations of trichloroacetic acid in the Table can be considered to represent the concentrations of total trichlorocompounds as well. These low concentrations were in sharp contrast to those found in the urine from factory workers exposed to trichloroethylene (120 to 250 p.p.m., 8 hours a day), where the levels of trichloroacetic acid and trichloroethanol are as high as $80 \mathrm{mg} . / \mathrm{l}$. and $130 \mathrm{mg} . / \mathrm{l}$. respectively (Tanaka and Ikeda, 1968).

The amounts of both hippuric acid and phenol in the normal urine were measurable. The levels of hippuric acid were slightly higher than those reported by Ogata et al. (1962). The difference might be due to the number of specimens examined. The phenol levels were roughly in agreement with or somewhat higher than those reported from various countries (Rainsford and Lloyd Davies, 1965; Walkley et al., 1961; Van Haaften and Sie, 1965).

TABLE

Levels of Hippuric Acid, Phenol, and Trichloroacetic Acid in normal Urine Samples

\begin{tabular}{|c|c|c|c|c|c|c|}
\hline & \multicolumn{4}{|c|}{ Students } & \multirow{2}{*}{\multicolumn{2}{|c|}{$\frac{\text { Factory workers }}{\text { Male }}$}} \\
\hline & \multicolumn{2}{|r|}{ Male } & \multicolumn{2}{|r|}{ Female } & & \\
\hline $\begin{array}{l}\text { No. of samples examined } \\
\text { Mean specific gravity } \\
\text { Creatinine (g./l.) }\end{array}$ & $\begin{array}{c}36 \\
1 \cdot 0 \\
1 \cdot 3\end{array}$ & $(0 \cdot 48-3 \cdot 68,20 \%)$ & $\begin{array}{l}30 \\
1.01 \\
0.89\end{array}$ & $(0 \cdot 24-2 \cdot 93,28 \%)$ & $\begin{array}{l}31 \\
1 \cdot 022 \\
1 \cdot 56\end{array}$ & $(0 \cdot 87-2 \cdot 79,11 \%)$ \\
\hline $\begin{array}{l}\text { Hippuric acid } \\
\text { Uncorrected (mg./l.) } \\
\text { Corrected with } \\
\text { Specific gravity (mg./l.) })^{1} \\
\text { Creatinine (mg./g. creatinine) }\end{array}$ & $\begin{array}{l}301 \\
290 \\
229\end{array}$ & $\begin{array}{l}(74-1266,11 \%) \\
(61-1385,14 \%) \\
(45-1174,15 \%)\end{array}$ & $\begin{array}{l}398 \\
570 \\
449\end{array}$ & $\begin{array}{l}(110-1431,11 \%) \\
(153-2125,10 \%) \\
(163-1242,8 \%)\end{array}$ & $\begin{array}{l}350 \\
291 \\
235\end{array}$ & $\begin{array}{l}(112-1084,10 \%) \\
(93-909,10 \%) \\
(78-711,10 \%)\end{array}$ \\
\hline $\begin{array}{l}\text { Phenol } \\
\text { Uncorrected (mg./l.) } \\
\text { Corrected with } \\
\text { Specific gravity (mg./l. })^{1} \\
\text { Creatinine (mg./g. creatinine) }{ }^{2}\end{array}$ & $\begin{array}{l}26 \cdot 1 \\
23 \cdot 3 \\
18 \cdot 9\end{array}$ & $\begin{array}{l}(8 \cdot 3-81 \cdot 5,18 \%) \\
(7 \cdot 3-73 \cdot 7,18 \%) \\
(6 \cdot 0-60 \cdot 1,20 \%)\end{array}$ & $\begin{array}{l}25 \cdot 2 \\
34 \cdot 8 \\
28 \cdot 5\end{array}$ & $\begin{array}{l}(8 \cdot 4-75 \cdot 5,17 \%) \\
(9 \cdot 8-123 \cdot 8,18 \%) \\
(11 \cdot 3-71 \cdot 7,14 \%)\end{array}$ & $\begin{array}{l}22 \cdot 8 \\
18 \cdot 2 \\
14 \cdot 5\end{array}$ & $\begin{array}{l}(8 \cdot 9-58 \cdot 3,15 \%) \\
(8 \cdot 0-41 \cdot 5,14 \%) \\
(7 \cdot 1-29 \cdot 9,14 \%)\end{array}$ \\
\hline $\begin{array}{l}\text { Trichloroacetic acid } \\
\text { Uncorrected (mg./l.) } \\
\text { Corrected with } \\
\text { Specific gravity (mg./l.) })^{1} \\
\text { Creatinine (mg./g. creatinine) })^{2}\end{array}$ & $\begin{array}{l}0-0 \\
0-2 \\
0-0\end{array}$ & & $\begin{array}{l}0-0 . \\
0-1 . \\
0-0 .\end{array}$ & & & \\
\hline
\end{tabular}

${ }^{1}$ Adjusted to a specific gravity of 1.016 .

${ }^{2}$ Metabolite concentrations divided by creatinine concentrations.

Numbers in the table are geometric means. Fiducial limit $(P=0.05)$ ranges and coefficients of variation of $\log _{10}$ [metabolite] are given in parentheses. In the case of trichloroacetic acid, minimum and maximum values observed are shown. In urine samples from 23 males and 21 females no Fujiwara reaction-positive substance was observed. 
In order to evaluate the significance of corrections for urine density, metabolite concentrations were corrected to a constant specific gravity of 1.016. Metabolite concentrations were also expressed relative to creatinine concentrations. Contrary to expectation that the corrected values would be less variable than the uncorrected values (i.e., the observed values), it was found that the corrected values were not always less variable than the uncorrected ones (see Table). It appears that correction for urine concentration either by correction to constant specific gravity (1.016) or to constant creatinine concentration does not lessen variation of normal urine samples.

The possible correlation between the specific gravity of urine and its creatinine concentration was also examined on 254 urine samples from male factory workers exposed to toluene or trichloroethylene or not exposed. The calculated regression line of the scatter diagram was:

$$
\mathrm{y}=0.0585 \mathrm{x}+0.2068
$$

where $\mathrm{y}=$ creatinine concentration (g./1.), and $\mathrm{x}=($ specific gravity -1.000$) \times 1,000$. Although the regression line passed quite close to the origin, the correlation coefficient ( $r$ ) was only 0.63 , indicating a rather poor correlation between specific gravity and creatinine concentration. Thus, correction to constant specific gravity may not replace correction to constant creatinine concentration, nor vice versa.

Thanks are due to Professor N. Miyata, Health Centre of Kyoto University, Kyoto, Japan, and to Dr. S. Inui and his associates, Kyoto Institute of Industrial Medicine, Kyoto, Japan, for their help in collecting urine samples.

\section{References}

Docter, H. J., and Zielhuis, R. L. (1967). Phenol excretion as a measure of benzene exposure. Ann. occup. Hyg., 10, 317-326.
Elkins, H. B., Comproni, E. M., and Pagnotto, L. D. (1963). Industrial benzene exposure from petroleum naphtha II. Pertinent physical properties of hydrocarbon mixtures. Amer. industr. Hyg. Ass. J., 24, 99-102.

- and Pagnotto, L. D. (1965). Is the 24-hour urine sample a fallacy? Ibid., 26, 456-460.

Folin, O. (1914). On the determination of creatinine and creatine in urine. J. biol. Chem., 17, 469-473.

Gaffney, G. W., Schreier, K., DiFerrante, N., and Altman, K. I. (1954). The quantitative determination of hippuric acid. Ibid., 206, 695-698.

Heath, D. F. (1967). Normal or log-normal: appropriate distributions. Nature (Lond.), 213, 1159-1160.

Ikeda, M. (1964). Enzymatic studies on benzene intoxication. $J$. Biochem. (Tokyo), 55, 231-243.

, and Kita, A. (1964). Excretion of p-nitrophenol and p-aminophenol in the urine of a patient exposed to nitrobenzene. Brit.J. industr. Med., 21, 210-213.

Ogata, M., and Nagao, I. (1968). Urinary m-methyl hippuric acid excretion and physiological changes in persons exposed to 200 p.p.m. $m$-xylene in an exposure chamber. Jap. J. industr. Hlth, 10, 75-79. (In Japanese.)

$\longrightarrow$, and Tomokuni, K. (1968). Urinary hippuric acid excretion in persons exposed to various concentrations of toluene in an exposure chamber. Ibid., 10, 64-74. (In Japanese.)

, Sugiyama, K., and Moriyasu, H. (1962). Studies on poisoning. IV. Toluene concentration in air and urinary hippuric acid measured by paperchromatography and mass screening examination method. Acta Med. Okayama, 16, 283-292.

Pagnotto, L. D., Elkins, H. B., Brugsch, H. G., and Walkley, J. E (1961). Industrial benzene exposure from petroleum naphtha. I. Rubber coating industry. Amer. industr. Hyg. Ass. J., 22, 417-421.

-, and Lieberman, L. M. (1967). Urinary hippuric acid excretion as an index of toluene exposure. Ibid., 28, 129-134.

Quick, A. J. (1931). The conjugation of benzoic acid in man. J. biol. Chem., 92, 65-85.

Rainsford, S. G., and Lloyd Davies, T. A. (1965). Urinary excretion of phenol by men exposed to vapour of benzene: A screening test. Brit. J. industr. Med., 22, 21-26.

Salmowa, J., Piotrowski, J., and Neuhorn, U. (1963). Evaluation of exposure to nitrobenzene. Ibid., 20, 41-46.

Soucěk, B., and Vlachová, D. (1960). Excretion of trichloroethylene metabolites in human urine. Ibid., 17, 60-64.

Tanaka, S., and Ikeda, M. (1968). A method for determination of trichloroethanol and trichloroacetic acid in urine. Ibid., 25, 214-219.

Van Haaften, A. B., and Sie, S. T. (1965). The measurement of phenol in urine by gas chromatography as a check on benzene exposure. Amer. industr. Hyg. Ass. J., 26, 52-58.

Walkley, J. E., Pagnotto, L. D., and Elkins, H. B. (1961). The measurement of phenol in urine as an index of benzene exposure. Ibid. 22, 362-367.

Received for publication June 17, 1968. 